\title{
Teses sobre resistências ao fascismo
}

\section{Theses on resistance to fascism}

\author{
André L. de Oliveira \\ Mendonça \\ Instituto de Medicina Social \\ (IMS-UERJ) \\ alomendonca@gmail.com
}

Recebido em 26/10/2018

Aceito em 25/11/2018

Ao amigo Paulo Paraizo (geólogo da Petrobras)

\section{Resumo}

Nesse ensaio ou "manifesto", eu narro, a passos largos, a história política do Brasil dos últimos 50 anos: do AI-5 de 1968 até as vésperas da eleição presidencial de 2018. Por meio de onze 'teses' - recurso livremente inspirado no clássico texto Teses sobre Feuerbach, de Karl Marx -, eu parto do diagnóstico da atual situação de "crise" que atravessamos, buscando suas causas mais remotas e indicando saídas de emergência para o futuro. A tese norteadora, por assim dizer, consiste na assunção de acordo com a qual nós estamos prestes a repetir 1968 como farsa (ou tragédia) porque, em certo sentido, o AI-5 nunca foi extinto (continuou vigorando para grande parcela de pobres e negros), bem como jamais fizemos um acerto de contas amplo, irrestrito e profundo com o período da Ditadura Civil-Militar. Outra tese crucial do ensaio é de que, a partir de 2013, ocorreu aquilo que denominei de 'colapso do concilialismo': contrariando a imagem fictícia de que seríamos cordiais e pacíficos, a recente explosão de violência, até então travestida, mostrou a verdadeira cara do Brasil. Por fim, proponho um movimento de autocrítica e de reinvenção das esquerdas na 'dramaticidade da hora atual', tomando emprestada a expressão de Paulo Freire empregada em seu seminal Pedagogia do Oprimido.

Palavras-chave: AI-5; Jornadas de Junho de 2013; Concilialismo Caboclo; Descolonização; Utopia Concreta

\section{Abstract}

In this essay or "Manifest", I narrate the political history of Brazil throughout the last 50 years (From AI 5 of the 1968 to the eve of the presidential elections of 2018). Through eleven theses - resource freely inspired in the classic text: Theses on Feuerbach by Karl Marx- I start from the diagnosis of the nowadays situation of crisis that we are going through at the moment, searching its very remote causes and showing a way-out of emergency for the future. The guiding thesis consists in the assumption that we are about to revive 1968 as farce (or tradegy) since, in a certain sense, the AI -5 has never been extinguished (it has kept in force for the majority of the poor and the black people), as well as we have never settled an ample, profound and unrestricted agreement with the period of Civil-Military Dictatorship. Another crucial thesis of the essay is that, as of 2013, the "Collapse of the conciliation", which I term, happened: opposing the fictitious image that we are cordial and pacific, a recent burst of violence, so far hidden, veiled the real face of Brazil. At last, I suggest a movement of self-criticism and reinvention of the left-wing parties in "the dramatization of the present hour", borrowing the expression employed by Paulo Freire in his seminal the Pedagogy of the Oppressed.

Key-words: AI-5; Journey of June of 2013; Cabloco Conciliation; Descolonization; Concrete Utopia 


\section{Um espectro ronda o Brasil - o espectro do fascismo}

Em seu germinal Pedagogia do Oprimido, escrito no exílio chileno em plena 'barra 68', Paulo Freire definiu como 'dramaticidade da hora atual' o momento pelo qual o mundo atravessava seu calvário em várias partes, ao mesmo tempo em que florescia o Maio francês. Exatos 50 anos depois, nossa história periga estar prestes a se repetir como farsa, ou, novamente, como tragédia (nosso "28 de brumário"?), parecendo corroborar a máxima paradoxal de que tudo que nós aprendemos com a história é que nós não aprendemos nada com a história. Os militares do autodenominado Comando Supremo da Revolução promulgaram o Ato Institucional Número 1 (AI-1) no dia 9 de abril de 1964, sob a alegação de que iriam livrar a sociedade brasileira da "ameaça comunista" - ou, mais precisamente, "do mar de lamas da corrupção" - e de que devolveriam a democracia ao povo tão logo reinasse a "ordem social". Sabemos hoje que esse fatídico dia, que pôs fim às Reformas de Base do Governo Jango, durou 21 anos. ${ }^{1}$ Sem deixar de reconhecer que, a rigor, não estamos ainda sob os maus auspícios de um AI-5 (desde o golpe 'temerário', passamos a ser regidos por um tipo de Ato Inconstitucional Número 1; com Lula preso e inelegível, por um Ato Inconstitucional Número 2...), acreditamos que a nossa 'dramaticidade da hora atual' é de tirar o sono, embora não o sonho, de modo mais perturbador do que em 64. ${ }^{2}$ De fato, sem entrar na discussão "técnica" sobre o tema, Bolsonaro tem uma característica central do fascismo "clássico" de dar inveja aos seus antecessores da Ditadura Civil-Militar: não há como subestimar o fato de ele ter se tornado uma liderança com forte apelo "popular", um "mito" como a direita até então não imaginara ser capaz de forjar na nossa história mais recente. ${ }^{3}$ Nesse aspecto, nenhum dos cinco presidentes militares é comparável a Bolsonaro. Em contrapartida, como não se pode negar também o relativo nacionalismo daquela geração de militares, provavelmente, hoje, os próprios generais estariam envergonhados com o entreguismo confesso do ex-capitão. Imagine o que pode vir a ser capaz de fazer um fascista eleito democraticamente, munido de respaldo político e clamor "popular" pelo fim dos "petralhas", "comunistas" e "bandidos", tal como Hitler em 1934 se sentira legitimado pelo voto daqueles que estavam excitados com a possibilidade de se fazer "justiça" contra os judeus e todos aqueles que não fossem da "raça ariana".

\section{A loucura da nova razão do mundo}

Visivelmente, Bolsonaro faz marketing político escrachadamente o tempo inteiro, dando pinta de que ele mesmo, pessoalmente, talvez, não seja tão linha dura quanto quer fazer parecer. Até pouco tempo atrás, ele e seu séquito costumavam afirmar que as vítimas de sua violência verbal, pessoas rotuladas de "turma do mimimi", haviam perdido o senso de "humor", como se declarações misóginas, racistas e homofóbicas pudessem ter alguma graça. Não se brinca, literalmente, com arma de fogo. Como era de se esperar, além da verbal, a violência física praticada pelos eleitores de Bolsonaro vem aumentando assustadoramente, especialmente a partir do $1^{\circ}$ turno das eleições e especificamente contra as minorias mais vulneráveis. Por sua vez, em função da atmosfera de violência que ele mesmo propaga, o próprio Bolsonaro foi vitimado por uma facada no dia 6 de setembro, véspera do desfile militar pela Independência. Independentemente de teorias conspiratórias acerca do atentado, à esquerda e à direita volver, não constitui um delírio pensar na possibilidade concreta de os generais da linha dura não quererem se sentir subordinados a um ex-capitão; a não ser que ele se sujeite a ser um mero boneco de fantoche dos seus interesses, usando de sua ascendência sobre o povo e mantendo, assim, uma aparência de "normalidade das instituições democráticas" para inglês ver. E

1 Daniel Reis, Marcelo Ridenti e Rodrigo Motta (2014) organizaram uma obra que é um verdadeiro acerto de contas com o golpe de 64 revisto 50 anos depois.

2 Não dá para acalentar o sonho de que, mesmo em caso de vitória do Haddad, o bolsonarismo irá recuar. Talvez, ocorra justamente o contrário: o ódio por parte dos ressentidos pode aumentar com a sensação de fracasso nas urnas. Sem contar que há fortes indícios de que a possibilidade de algum tipo de intervenção fora do "jogo democrático" possa vir a se concretizar.

3 Faz-se urgente repensar o fascismo em suas múltiplas dimensões (da mais especificamente política à psicologia das massas), reativando o 'alarme de incêndio' disparado (porém pouco ouvido) por Gramsci, Benjamin, Adorno, Reich, entre outros.

4 O título dessa tese é uma fusão livremente inspirada nos títulos de duas obras indispensáveis para se pensar o capitalismo neoliberal: Pierre Dardot \& Christian Laval (2010) e David Harvey (2018). 
não nos agarremos à fábula de que na atual geopolítica não teria espaço para ditaduras. ${ }^{5} \mathrm{~A}$ primeira objeção a essa doce ilusão é a de que vivemos sob uma ditadura do mercado, que deixa de ser simbólica e passa a ser real sempre que se faz necessário; a segunda, diretamente relacionada à primeira e mais importante ainda, é a de que vivemos uma conjuntura na América Latina de sucessivos "golpes à paraguaia" (Zelaya em 2009; Lugo em 2012; Dilma em 2016). Mesmo com todos os seus problemas, o "socialismo do século 21" (Bachelet, Chávez, Cristina e Néstor Kirchner, Lula, Morales, Fernando Lugo e Rafael Correa) incomodou as corporações que mandam no mundo... ${ }^{6}$ Em comum nos três casos de golpe foi o uso da caneta em lugar da baioneta. Não foi preciso nem ostentar armas; o judiciário se impõe pelo rito "democrático", com auxílio da grande mídia. ${ }^{7}$ Os generais, se precisarem tirar Bolsonaro de cena, terão o STF para pavimentar o caminho, e a "violência travestida seguirá fazendo seu trottoir". Não nos esqueçamos: no período de chumbo, Médici era aplaudido no Maracanã lotado, com 200 mil pessoas, enquanto um torturador seguia suas ordens no mesmo horário. A vida seguia seu curso, "normalmente".

\section{13 de dezembro de 1968, o dia que não terminou}

O que estamos vivendo são ainda os desdobramentos imponderáveis do AI-5, o mais duro golpe contra as cabeças pensantes brasileiras dentre os dezessete decretos emitidos. Com o poder totalitário atribuídos aos militares por si próprios, porém com a adesão de vários segmentos da 'elite do atraso' (parte considerável do empresariado, da imprensa, do judiciário, das igrejas etc.), o Brasil entrou em um dos períodos mais horrendos da sua história naquela agourenta sexta-feira 13. Corpos barbarizados nos porões da ditadura, almas dilaceradas pela tortura; vidas promissoras ceifadas, jovens brilhantes enlouquecidos. Ao povo a "vida de gado" na "fazenda modelo"; aos intelectuais, artistas, professores e estudantes a "opção" de "amar ou deixar o Brasil". " Indo além de terra brasilis, a Operação Condor, que sobrevoou quase toda a América Latina, cortou-nos as asas da liberdade com o aval e, sobretudo, o incentivo do imperialismo norte-americano, conforme os documentos oficiais de Estado caídos em domínio público comprovam. Quando passaram-se os anos, a verdade é que nuestros hermanos latinos, especialmente argentinos e uruguaios, levaram mais a fundo o acerto de contas com a memória histórica em suas respectivas Comissões da Verdade, ao passo que nós aqui buscamos uma espécie de conciliação do irreconciliável. ${ }^{9}$ Os militares nunca saíram totalmente de cena e estiveram sempre à espreita, o que, hoje está escancarado para todos. E quase tão dramático quanto: a nossa polícia militar é filhote da ditadura e jamais perdeu esse "DNA" de violência, especialmente relação à população preta e pobre. UPP: a redução da favela a três letras, dissertação emblemática de Marielle Franco, não nos deixa mais omitir essa "verdade tropical" acerca das tropas da ralé. Em certo sentido, o AI-5 vige ainda nas favelas e comunidades de várias cidades brasileiras, especialmente nas do Rio $40^{\circ}$, "cidade maravilha", purgatório da beleza e do caos. Voltará a ser a lei aplicada a todos os "subversivos" e/ou "corruptos", em uma espécie de retorno do nunca totalmente recalcado? Oxalá que não. Não volte o fantasma da tortura nunca mais a nos atormentar. ${ }^{10}$ Bolsonaro já chegou a declarar que o problema da ditadura foi ter "apenas"

5 Com evidente interesse na camada do pré-sal, as grandes corporações não medem esforços para se apropriarem do nosso petróleo. Não soa mera "teoria da conspiração" estabelecer associação, conforme vários analistas políticos vem defendendo, entre o golpe de 2016, o discurso da corrupção ("petrolão") e o novo marco de regulação do petróleo. Interesses geopolíticos, como a história nos mostra sobejamente, já instaram superpotências a contribuírem com o advento de regimes ditatoriais em várias regiões mais pobres, tal como já o fez os EUA na América Latina e no Oriente Médio.

6 Não se pode deixar de reconhecer também que os EUA, com as devidas ressalvas que a nova configuração geopolítica nos obriga fazer, continuam mandando no mundo. Ver Noam Chomsky (2017).

7 Sobre o golpe no Brasil (ainda em curso por ocasião de sua publicação), tendo como pano de fundo os golpes na América Latina referendados pelo judiciário, consultar, por exemplo, Jean Tible (2016).

8 A respeito dos expurgos e 'operações de limpeza' nas universidades brasileiras durante a ditadura, vale a pena ler o livro de Rodrigo Motta (2014).

9 A ausência de punição para os culpados contrasta com a contundência do Relatório Final da Comissão Nacional da Verdade acerca das graves violações de direitos humanos cometidas pelo Estado brasileiro.

10 Durante o período da ditadura, a tortura foi "aprimorada" aqui no Brasil e na América Latina com o auxílio dos militares franceses, que utilizavam-na pelo menos desde a Guerra da Argélia. Cf. Leneide Duarte-Plon (2016). Ao contrário do que se supunha, mesmo sendo 'crime contra a humanidade', a prática da tortura vem se disseminando no mundo "civilizado" e nos países "democráticos". 
torturado, em lugar de ter matado todos os "subversivos". O mesmo que é dito pela personagem de um militar na obra-prima Uma noite de 12 anos - filme sobre a barbárie da ditadura uruguaia vivida por José Pepe Mujica e mais dois de seus companheiros tupamaros -, na atuação de César Troncoso (ator que fez, em "compensação", o revolucionário Esnal em A outra história do mundo).

\section{01984 das Diretas nunca derrotou o '1984' da direita para sempre}

Entre março de 1983 e abril de 1984, respirando um pouco mais aliviado, o Brasil transpirou entusiasmo graças à atmosfera de novos ventos vindos, não das "noites do Norte", da própria energia solar da América do Sul. Fruto do batismo de sangue da geração dos anos 60, o renascimento do espírito democrático batizado de "Diretas já" foi um movimento suprapartidário que, se não conseguiu alcançar seu anseio maior pelo voto direto para Presidente, fez os militares baterem em revoada para seus quartéis e reaprenderem suas antigas lições. Saudades de um tempo em que o Hino Nacional ainda não era uma bandeira exclusiva da direita: Fafá de Belém realizou a façanha de trazer à tona, em seu tom à flor da pele, mensagens subliminares jamais imaginadas na letra irrealista composta pelo poeta parnasiano Osório Duque-Estrada. Nostálgico também e melhor ainda é ouvir o "hino nacional" daquele tempo jamais ido: "Quero falar de uma coisa/Advinha onde ela anda/Deve estar dentro do peito/Ou caminha pelo ar". Além do "coração de estudante" cheio de sonhos de liberdade e de esperança por igualdade, tínhamos outra coisa em comum: um inimigo claro contra o qual lutar (prestes a ser derrotado àquela altura): a Ditadura Civil-Militar. A força da nossa união foi o que venceu nossos algozes? Sim. Não definitivamente. O romance distópico 1984, de George Orwell, voltou a ficar mais atual do que nunca. $\mathrm{O}$ ovo da serpente do totalitarismo nos parece estar sendo chocado em várias partes do mundo: da ultra-direita europeia a Trump. ${ }^{11} \mathrm{E}$ tem boa gente nossa que ainda cai na cantilena neoliberal de que políticos com personalidade autoritária não interessam ao mercado, justamente a entidade-mor totalitária do nosso tempo. ${ }^{12}$ Não seria ele, o mercado, ente abstrato e ao mesmo tempo muito real, a encarnação do "Grande Irmão" orwelliano a vigiar as sociedades ocidentais, ininterruptamente, de modo a não permitir que nada coloque em xeque sua checklist do Consenso de Washington cada vez mais fundamentalista? As denúncias comprovadas de Julian Assange e Edward Snowden referentes ao sistema de vigilância global não deixam nutrirmos ilusões a respeito do "amor" que o neoliberalismo possui pela democracia. Infelizmente, reconquistamos a democracia no momento histórico em que ela estava sendo igualada com o capitalismo mais selvagem, jamais previsto pelos liberais dos séculos anteriores. Símbolo-mor da onda neo-conservadora dos anos 1990, o filósofo Francis Fukuyama disse que a história tinha chegado a um fim, o das sociedades de "livre" mercado. Poucos não acreditaram...

\section{Não há capitalismo com "face humana"}

Tendo sido o primeiro presidente civil eleito pela via do voto direto no período pós-ditatorial, Fernando Collor inaugura os anos 1990 com a falsa promessa de acabar com a corrupção e com os "marajás", alegando que iria modernizar o Brasil por meio da abertura de sua economia à "nova ordem mundial da globalização".

11 Mesmo sendo um partidário da "democracia formal" e sem examinar o recrudescimento da ultra-direita, David Ruciman (2018: 10) chama a atenção para a possibilidade de fim da democracia na era pós-Trump através do paradoxo de ela existir já tendo acabado: "A grande questão do século XXI é saber por quanto tempo poderemos manter os arranjos institucionais em que estamos tão habituados a confiar, a ponto de nem notar mais quando pararam de dar resultado. As eleições regulares são um desses arranjos e continuam a ser o grande alicerce da política democrática. Mas também envolvem corpos legislativos democráticos, tribunais independentes e uma imprensa livre. Todos eles podem continuar a funcionar da maneira habitual, mas sem nos proporcionar o que deviam garantir. Uma versão esvaziada da democracia tem o perigo de nos acalentar com uma falsa sensação de segurança. Podemos continuar a confiar na democracia e recorrer a ela como salvação, ao mesmo tempo que fervemos de irritação com sua incapacidade de corresponder às nossas expectativas. A democracia pode entrar em falência mesmo permanecendo intacta".

12 Excelente desmascaramento da associação feita entre comunismo e totalitarismo, bem como consistente demonstração da conexão entre "totalitarismo" e mercado/nova direita, é feito por Slavoj Zizek em vários momentos de sua obra (e.g.: 2013). 
Adotando, a rigor, assim, o traje neoliberal engomado, a começar, literalmente, pelo próprio jeito de se vestir e de exibir o "corpo sarado" devido à prática de cooper e jetski. Sabemos hoje do desfecho dessa história: "caras-pintadas" coloriram o Brasil com o impeachment de Collor, que, infelizmente, ressurgiu na vida pública como senador (PTC). Não podemos nos esquecer de que, naquele contexto, o Muro de Berlim havia acabado de ser derrubado, simbolizando a "derrocada" da Guerra Fria, do socialismo e das grandes utopias; a "moda" agora era defender a "livre inciativa" e a "liberdade do indivíduo". Não soava mais feio se assumir individualista e utilitarista. Margaret Thatcher, a "Dama de Ferro", acertou a mosca na sopa em cheio, quando ela disse (em livre tradução): "A economia é o método. O objetivo é mudar o coração e a alma". Juntamente com Ronald Reagan, após o experimento fascista pioneiro de Augusto Pinochet, ${ }^{13}$ ela foi a grande responsável, não apenas pela implementação de sua política econômica austericida, pela propagação do ideário neoliberal formulado pelos intelectuais da Sociedade Mont Pèlerin ( domina nossas almas. Intelectuais esses que disseminaram a ideologia anti-comunista - propagandeando inverdades convenientes a respeito do "socialismo real" - e inspiraram a criação de think tanks mundo afora, esses "tanques de guerra" a travar uma batalha suja, porque pautada geralmente pela mentira, no campo das ideias. ${ }^{14}$ É por isso que, a despeito da pertinência do debate acerca da dose de inclusão social - contrária ao receituário amargo neoliberal? -, adotada por FHC e por Lula/Dilma, o fato inconteste é que, em ambos os casos, a alma nacional não deixou de ser tocada pelo modo de ser neoliberal (tudo visou a resultar em resultado, coisificando-nos). Sem comentários quanto a Temer... ${ }^{15}$ Ressalva importante e conclusiva: foi durante a era Lula/Dilma que vários atores até então fora do espaço público começaram a desempenhar papel de destaque: mulheres, negros, povos originários, LGBTTTs. Origem do ódio ululante atual?

\section{2013 não foi o ano que criou Bolsonaro}

No retrovisor, a imagem que costuma aparecer para grande parte da esquerda é a do bolsonarismo se constituindo durante as manifestações que tomaram conta das ruas em 2013, as Jornadas de Junho. Sem deixarmos de reconhecer que os adeptos de Bolsonaro perderam completamente a vergonha após 2013, chegando hoje ao exibicionismo patológico do trogloditismo, não podemos concordar com essa adoção da 'lógica do sentido' à la Alice no País das Maravilhas, tomando a causa por consequência e vice-versa. Refrescando a memória, o grande disparador das Jornadas foram as manifestações, iniciadas em São Paulo contra o aumento da tarifa de ônibus, convocadas pelo Movimento Passe Livre (MPL) - grupo inspirado em várias lutas anteriores, tais como Revolta do Buzu (Salvador, 2003) e Revolta da Catraca (Florianópolis, 2004). Como a obra coletiva Cidades Rebeldes: Passe Livre e as manifestações que tomaram as ruas do Brasil permite apreender, tratava-se de um grupo bem organizado e guiado por valores libertários e genuinamente democráticos, responsáveis por tocarem em um vespeiro às vésperas da Copa das Confederações: por meio de uma pauta aparentemente específica (tarifa de transporte), eles propiciaram que viessem à tona praticamente todos os problemas da vida contemporânea das grandes cidades (saúde, educação, moradia, segurança etc.), uma vez que sem circulação, sem mobilidade urbana, o sistema como um todo colapsa (lição sabida pelos caminhoneiros...). Agora, sem sugerir culpabilização alguma, o fato é que o MPL saiu de campo logo após ter ficado evidente que algumas das reinvindicações e dos grupos que estavam indo para as manifestações não eram identificados com bandeiras da esquerda; assim, se no começo a presença de grupos fascistóides era minoritária, com o tempo ela se tornou hegemônica. Vácuo existe na lei da física, não em política. Nos estádios de "Padrão Fifa", durante a realização da Copa do 7x1, a classe média conservadora e a "elite do atraso" continuavam cantando o Hino Nacional mesmo após o fim da sua execução oficial, enquanto isso lá

13 Pouco se analisa a relação entre fascismo e neoliberalismo ocorrida durante a ditadura de Pinochet, mas, ainda assim, só essa experiência histórica por si só já seria suficiente para desfazer o mito de que o capitalismo faz um par indissolúvel com a democracia.

14 David Harvey (2005) nos municia com uma história sucinta, porém consistente e instrutiva, sobre o neoliberalismo.

15 O Governo Temer, apesar do "totalitarismo" mercadológico contrário a direitos sociais e trabalhistas, não possui um viés autoritário "clássico", ao passo que Bolsonaro promete unir economia neoliberal com política ditatorial, em um tipo de combinação bombástica explosiva: \#ForaTemer; \#EleNunca. 
fora as manifestações, já meio esvaziadas, eram cada vez mais duramente reprimidas pela Polícia Militar. ${ }^{16}$ Em 2015, a direita virou o jogo e ajudou a consolidar o golpe em marcha, voltando a encher as ruas, aí sim sozinha, de verde e amarelo B(r)azuca. ${ }^{17}$ Que a direita, no discurso (falso), apropria-se há tempos de todas as bandeiras da esquerda não é novidade, mas que ela seria capaz de adotar uma prática de luta historicamente de esquerda não constava na teoria social.

\section{0 que colapsou foi o 'concilialismo caboclo'}

É preciso lutar por uma narrativa que coloque as Jornadas de Junho de 2013 em seu devido lugar. Conforme a obra coletiva Occupy: movimentos de protesto que tomaram as ruas nos mostra, o que está em jogo é uma geração de jovens que vem reinventando a esquerda no mundo - desde a Primavera Árabe e o Movimento Occupy pós "crise" de 2008 -, lançando mão de novas táticas de ação direta e dando adeus a velhas formas de organização verticalizadas e hierarquizadas. Será que, novamente, estaria ocorrendo a feliz comunhão entre espírito libertário de tradição anarquista e atitude revolucionária de tradição socialista? ${ }^{18}$ No Brasil, o movimento social de ocupação das escolas em São Paulo, ao final de 2015, foi o melhor presente de Natal que poderíamos receber naquele triste ano: jovens secundaristas de 200 escolas se organizaram e impediram que Alckmin fechasse suas respectivas escolas sob o pretexto de realocar os estudantes. O livro Escolas de Luta é leitura obrigatória para quem quiser aprender a lição dada pelos estudantes, essas 'flores belas' que brotaram após as várias primaveras ao redor do mundo. Lindamente, em 2016, elas também desabrocharam em várias outras cidades brasileiras, inspirando-se na Revolta dos Pinguins - o movimento dos secundaristas chilenos, em 2006 e 2011. Não temos dúvidas de que a direita soube tirar proveito de todas essas demonstrações de insatisfação - especialmente das Jornadas de Junho -, mas, de qualquer forma, faz-se oportuno lembrar que naquela ocasião Dilma desfrutava ainda de uma relativa popularidade. Seja como for, o ponto é que, após 2013, não tem mais caminho de volta. O Brasil mostrou sua cara: ela não é bonita do modo como o espelho de conto de fadas nos queria fazer crer, é a cara da morte. Nós não somos pacíficos, não somos uma "democracia racial"; nós somos violentos: Lélia Gonzalez está aí para refutar Gilberto Freyre. O "concilialismo" que parece nos constituir (essa ideologia do "homem cordial") é só um jogo de aparências: por trás das coalizões escondem-se as colisões. Infelizmente, quem vai mais sofrer com a violência (no caso, a física), que promete aumentar e se escancarar daqui por diante, são as pessoas em condições mais vulneráveis, o que já vem acontecendo. Contudo, ainda assim, é preciso reconhecer o legado de 2013 no plano simbólico, real e imaginário: que ninguém mais se sinta à vontade para fazer o discurso hipócrita de que o Brasil é uma "nação historicamente unida". Luta de classes, luta de gêneros, luta de raças haviam voltado, ou, na realidade, nunca tinham ido; apenas passaram a ocupar o espaço público.

\section{A colisão desarmada é limitada, porém possível, ou, possível, porém limitada}

Se por trás de toda coalizão alarmada tem de fato muita colisão silenciada, o concilialismo de conotação lulista não teria como dar certo por muito tempo; ou, talvez, esse arranjo só possa permanecer harmônico sob a condução da batuta de um "líder carismático". Desfrutando do olhar retrospectivo privilegiado (quem pode estar em situação confortável na "dramaticidade da hora atual" de quartéis em prontidão?), o tão propalado bloco dos cinco "Bs" (bancadas da Bala, Banco, Bíblia, Betoneira e Boi) não teria como continuar dando certo, se se quisesse efetivamente incluir sem restrições o bloco dos três "Ps" (Pretos, Pobres e "Psicóticos"). Sem espaço para decifrar o enigma do lulismo por ora - não faltam obras que o façam com competência no

16 Recentemente, criminalizando atos políticos, a Lei Antiterrorismo (13.260/2016) condenou vários manifestantes de 2013, incluindo o jovem negro Rafael Braga, preso político desde aquela época.

17 Apropriando-se da teoria do discurso de Ernesto Laclau, Célia Pinto (2017) narra o deslocamento discursivo em direção à onda conservadora a partir de três momentos sucessivos das manifestações (2013, 2014 e 2015).

18 Sobre o feliz encontro dessas duas tradições de pensamento e de luta, ocorrido ao longo da história e com bons indícios de reencontro no futuro próximo, ver Olivier Besancenot e Michael Löwy (2016). 
pensamento de esquerda -, o ponto é que Lula dispôs de condições objetivas, por assim dizer, mais favoráveis do que sua sucessora para tentar superar a coalizão em direção à colisão, ainda que de modo reformista; não obstante, ele não o fez. ${ }^{19} \mathrm{Na}$ nossa leitura, parecida com a de André Singer (2015), a genealogia do golpe começa, em lugar das manifestações de 2013, com o pronunciamento de Dilma no dia 30 de abril de 2012, por ocasião do $1^{\circ}$ de Maio. Nele, nossa primeira presidenta fez uma dura crítica ao sistema financeiro e aos altos juros bancários, ensejando a chamada "guerra dos spreads". Naquela mesma semana, começou um verdadeiro massacre midiático, indo de $O$ Globo a veículos ao redor do globo, contra a "irresponsabilidade fiscal” de Dilma. ${ }^{20}$ Todos os 'aparelhos ideológicos de mercado' (instituições financeiras responsáveis por defenderem os interesses dos donos do "mundo globalizado": Banco Mundial, FMI, OCDE etc.) desencadearam uma ação orquestrada. Diante desses ataques, somados à conjuntura interna desfavorável, Dilma não teve mais condições de radicalizar em direção à colisão; precisou recuar, a ponto de chamar o pró-mercado Joaquim Levy para substituir Guido Mantega no Ministério da Fazenda. Àquela altura, a coalizão costurada pelo lulismo já havia dissolvido por conta de duas novas variáveis no tabuleiro, respectivamente: 1- nova acomodação das commodities; 2 - advento da Lava-jato. Com a escassez dos recursos necessários ao jogo do toma-lá-dá-cá e com o moral do Moro elevada, os ratos e suas pulgas começaram a pular do navio antes de ele afundar (eles tinham ilhas de paraísos fiscais para aportarem). No histórico 17 de abril de 2016, assistimos a um "teatro dos vampiros" horripilante dirigido por Eduardo Cunha, no qual 367 deputados crucificaram a ex-presidente Dilma, em nome de Deus e da família.

\section{IK. É preciso fazer política para se criar vínculos sociais, e não o contrário}

Estamos cônscios de que, qualquer que terá sido o resultado eleitoral do dia 28, nós não teremos trégua no Brasil nos próximos anos; com o drama adicional de que os conflitos no século XXI muito provavelmente serão potencializados, cada vez mais, pela "condição de pós-verdade", ou pelas fake news. ${ }^{21}$ Nesse sentido, é preciso reconhecer que as redes sociais não estão necessariamente do nosso lado, como nos quis fazer crer Manuel Castells em seu belíssimo Redes de indignação e esperança: movimentos sociais na era da internet. ${ }^{22}$ Em seu seminal História e consciência de classe, dentre tantas teses ainda pertinentes, Lukács se colocava diante da questão da necessidade de o comunismo criar suas próprias tecnologias, uma vez que ele não as tomava como neutras (elas seriam decorrentes da divisão capitalista do trabalho); em sua linguagem, seria necessário revolucionar, além das relações de produção, os modos de produção. O que ele diria hoje a respeito de um tempo em que a própria tecnologia virou, mais do que um meio, o princípio e fim das nossas sociedades? Independentemente da atualidade das ideias de Lukács, o fato é que, sem querer ser "apocalíptico e desintegrado", as atuais formas de constituição de vínculos sociais - cada vez mais mediatizadas por tecnologias pautadas segundo o "princípio" da obsolescência programada acelerada - parecem estar nos conduzindo rumo à era "pós-humana", para não dizer em direção àquilo que eu quero aqui cunhar de "barbárie tecnológica". É possível construir vínculos humanos efetivos e afetivos através de máquinas aparentemente projetadas para nos dominarem, bem como para tirarem a nossa atenção das coisas que realmente deveriam importar? Se pararmos para pensar bem, talvez possamos perceber que nós estamos criando laços cada dia mais superficiais com as pessoas tendo em vista fazer a política do interesse, do resultado (mesmo que seja a boa intenção de reverter uma "má" intenção de voto), ao invés de fazermos a política dos afetos motivada pela finalidade de construir vínculos profundos e duradouros. Não consigo vislumbrar outra possibilidade para a retomada de um projeto político autêntico que não passe pelo contato físico, pela presença real de corpos no trabalho, nas ruas, nas casas, seja mais onde for. Nos tempos vindouros, o grande desafio consistirá em deixarmos de ser esses zumbis (mortos-vivos) conectados a redes

19 Dentre um número já considerável de produção acerca do lulismo, vale a pena conferir a obra coletiva organizada por André Singer e Isabel Loureiro (2016).

20 Tales Ab’Sáber escreveu um livro sobre o lulismo (2014) e outro sobre Dilma (2015), ambos necessários para uma compreensão mais arguta dos Governos PT.

21 Ainda que meros defensores da 'democracia liberal', cabe aqui dar dicas de duas obras sobre fake News na era da pós-verdade de Trump/Bolsonaro: Matthew D’Ancona (2018) e Michiko Kakutani (2018)

22 Mussolini e Hitler, "mestres" da propaganda fascista, hoje diriam eufóricos: "deem-me um WhatsApp e eu dominarei o mundo". 
fantasmagóricas e passarmos a ser cada um de nós como que um novo Zumbi dos Palmares, grande símbolo da resistência e consciência negras, reconectando-nos com algum tipo de ancestralidade.

\section{K. Por novas "CEBs" seculares e descolonizadas}

As "ações diretas" sempre foram vistas no interior da esquerda como uma prática indispensável, tendo em vista à transformação mais profunda da realidade social por intermédio de operações pontuais e momentâneas. Concomitantemente, o cultivo de um ethos coletivo mais morosamente construído através de um processo formativo também fez parte do imaginário social da esquerda. Ambas as frentes de trabalho - atuação coletiva objetiva e formação de qualidades subjetivas - costumavam fazer parte de uma visão de mundo totalizante (e não totalitária) na qual se pretendia mudar a ordem social capitalista, recorrendo-se a um processo revolucionário socialista/comunista. Com o fim da Guerra Fria e consequente esmorecimento do socialismo, parece ter sobrado à esquerda a "alternativa" única da via democrática. Não tem quem não fetichize a democracia burguesa. Rosa Luxemburgo já havia nos ensinado a lição faz tempo: só é possível democracia real no socialismo e vice versa. Por dentro do sistema, mesmo que se passem 20 anos emendando eleição após eleição, só é possível fazer reformas, i.e., mudanças superficiais calculadamente consentidas pela direita. Lá se vão trinta anos dessa experiência político-eleitoral no mundo e parece que nós "voltamos a viver como trinta anos atrás", e, agora, com o risco de no caso brasileiro "retornarmos quarenta, cinquenta anos no tempo", como tem afirmado Bolsonaro. Os jovens já estão reinventando as ações diretas, falta agora resgatarmos, juntos, a formação de novas qualidades subjetivas junto ao povo. As Comunidades Eclesiais de Base (CEBs), que aprenderam com experiências revolucionárias (e.g.: círculo de cultura e educação popular), foram um verdadeiro cimento da cultura política e da política cultural latino-americanas nos idos 1960/1970 (não à toa foram asfixiadas pelo conservador João Paulo II e estão sendo recuperadas pelo Papa Francisco), pois os 'religiosos da libertação' iam morar nas próprias favelas, compartilhando o sofrimento e as esperanças do povo. Como poderemos voltar a fazer trabalho similar, nós que somos da esquerda secular? Não sabemos ainda o "como" fazer, mas ao menos que é este o nosso "quê fazer". Sem abandonar as instituições, carentes de revitalização e arejamento, abramos espaço para a convivialidade humana. Abramos nossas casas para saraus, façamos círculos nas casas das pessoas mais "simples de coração". Reconexão com os "seres vivos". Comunismo franciscano? Talvez. Mas, dessa vez, tupiniquim. Sem virar as costas totalmente para a Europa, precisamos 'redescobrir o Brasil real', e enterrar de vez o 'burlesco e caricato'.

\section{KI. Já só uma 'utopia concreta' nos pode ainda salvar}

Em tempos sombrios, é bom lembrar que "Onde cresce o perigo, surge também o que salva". Independentemente do resultado do dia $28,{ }^{23}$ nós estamos tendo a oportunidade histórica de reinventar nossas subjetividades e de recriar nossa vida coletiva. Seria uma grande injustiça e equívoco dizer que nós erramos fragorosamente nos últimos anos, mas, de qualquer forma, vai ser necessário recomeçar pelas bases. É duro de aceitar; não há como denegar: grande parte do êxito atual da direita no mundo vem de sua capacidade de mobilizar, embora manipulando, as pessoas pelos afetos (e.g.: ódio). Nós não podemos abdicar da ética (morada do "belo", "justo" e "verdadeiro"); por outro lado, nós precisamos envolver as pessoas e a nós mesmos em projetos coletivos que nos deem um sentido maior da vida em comum (comunismo). Apostar tudo no jogo eleitoral é pensar e agir na medida restritiva de quatro anos. Não temos o direito de sonhar pelas gerações dos anos 3000 (a não ser lutar para que elas ainda tenham um planeta habitável), porém temos o dever de sonharmos "um sonho que se sonha junto" que vá além de imediatismos e pragmatismos. Que as mulheres negras sejam o grande farol a nos guiar. A salvação só virá dos "esfarrapados do mundo". Se o lema de Bolsonaro é "Não foi você" (subentende-se: foi o PT), o lema de Marielle, símbolo de resistência para os

23 Nós da comunidade uerjiana estamos especialmente apreensivos com a possibilidade de vitória do "aventureiro" Wilson Witzel, assumidamente um fascista bolsonarista. 
anos vindouros, é "Eu sou porque nós somos". Só o coletivo salva. Que a sabedoria ancestral advinda de olhos cor de lágrima possa abrir nossos caminhos:

E também, já naquela época, eu entoava cantos de louvor a todas as nossas ancestrais, que desde a África vinham arando a terra da vida com as suas próprias mãos, palavras e sangue. Não, eu não esqueço essas Senhoras, nossas yabás, donas de tantas sabedorias. Mas de que cor eram os olhos da minha mãe? (EVARISTO, 2017: 18)

O ódio que a "elite do atraso" remói por Lula é, no fundo, o ódio que ela nutre contra o que considera "lixo humano", especialmente contra as mulheres negras que começaram a exibir suas belas madeixas orgulhosamente e a ocupar seu lugar de fala sábia. Ou será que seu ódio é um amor enrustido, não correspondido? É tempo de ler as intelectuais negras (de Maria Firmina dos Reis a Djamila Ribeiro, passando por Sueli Carneiro), de modo a obtermos outro pensamento social brasileiro: à luz (negra) de uma nova interpretação mais realista e imaginativa, haveremos de transformar o Brasil, verdadeiramente! Aprendamos, enfim, com aquelas que souberam falar pelos orifícios das máscaras...

\section{Agradecimentos}

A Antonio Videira pela inestimável contribuição, tendo sido o grande responsável para que o texto ganhasse coerência entre 'forma' e 'conteúdo';

A Katia Reis por ter me chamado a atenção para questões pontuais importantes, tanto as presentes quanto as ausentes no manuscrito original;

Ao editor do Dossiê, Leonardo Miguel, pela generosa oportunidade, e aos pareceristas pelas sugestões.

\section{Referências Bibliográficas}

AB'SABER, Tales. Lulismo: Carisma pop e cultura anticrítica. São Paulo: Hedra, 2014.

Dilma Roussefe ódio político. São Paulo: Hedra, 2015.

BESANCENOT, Olivier; LÖWY, Michael. Afinidades revolucionárias: nossas estrelas vermelhas e negras. Por uma solidariedade entre marxistas e libertários. Tradução: João Alexandre Peschanski e Nair Fonseca. São Paulo: Unesp, 2016.

CHOMSKY, Noam. Quem manda no mundo? Tradução: Renato Marques. São Paulo: Planeta, 2017.

D’ANCONA, Matthew. Pós-verdade: a nova guerra contra os fatos em tempos de fake News. Tradução: Carlos Szlak. Barueri: Fardo Editorial, 2018.

DARDOT, Pierre; LAVAL, Christian. La nouvelle raison du monde: essai sur la sociéte néolibérale. Paris: La Découverte, 2010.

DUARTE-PLON, Leneide. A tortura como arma de guerra - Da Argélia ao Brasil: Como os militares franceses exportaram os esquadrões da morte e o terrorismo de Estado. Rio de Janeiro: Civilização Brasileira, 2016.

EVARISTO, Conceição. Olhos d’água. Rio de Janeiro: Pallas, 2016.

HARVEY, David. A brief history of neoliberalism. New York: Oxford University Press Inc., 2005.

po, 2018.

A loucura da razão econômica: Marx e o capital no século XXI. Tradução: Arthur Renzo. São Paulo: Boitem-

KAKUTANI, Michiko. A morte da verdade: notas sobre a mentira na era Trump. Tradução: André Czarnobai e Marcela Duarte. Rio de Janeiro: Intrínseca, 2018.

MOTTA, Rodrigo. As universidades e o regime militar: cultura política brasileira e modernização autoritária. Rio de Janeiro, Zahar: 2014. 
PINTO, Célia. A trajetória discursiva das manifestações de rua no Brasil (2013-2015).Lua Nova, No100, 2017: 119 -155. REIS, Daniel; RIDENTI, Marcelo; MOTTA, Rodrigo (Org.). A ditadura que mudou o Brasil: 50 anos do Golpe de 1964. Rio de Janeiro: Zahar, 2014.

RUNCIMAN, David. Como a democracia chega ao fim. Tradução: Sergio Flaksman. São Paulo: Todavia, 2018.

SINGER, André. Cutucando onças com varas curtas: O ensaio desenvolvimentista no primeiro mandato de Dilma Roussef (2011-2014). Novos Estudos, № 102, 2015: 39-67.

SINGER, André; LOUREIRO, Isabel. As contradições do lulismo: a que ponto chegamos? São Paulo: Boitempo, 2016.

TIBLE, Jean. Golpe à Brasileira. Revista Política Latino Americana, No2, 2016: 1-22.

ZIZEK, Slavoj. Alguém disse totalitarismo? Cinco intervenções no (mau) uso de uma noção. Tradução: Rogério Bettoni. São Paulo: Boitempo, 2013. 